\title{
Chemical Composition, Antimicrobial and Antioxidant Activities of the Essential Oil of Bursera graveolens (Burseraceae) From Perú.
}

\author{
Alejandrina Honorata Sotelo Mendez, Clara Gabina Figueroa Cornejo, Mary Flor Césare Coral, María \\ Cecilia Alegría Arnedo*
}

La Molina Calidad Total Laboratorios -Universidad Nacional Agraria La Molina, Av La Universidad s/n. Lima 12, PERÚ.

\begin{abstract}
Palo santo oil is an important component of the traditional Peruvian medicine and is known to have antibacterial properties. This essential oil is extracted from fallen branches of the tree $B$. graveolens. To validate some of its properties, the antimicrobial and antioxidant activities of palo santo oil obtained from northern Peru were first examined. Based on the measurements of the diameter of growth inhibition (Agar Disc Diffusion method), antimicrobial activities ranging from moderate to high were revealed against Staphilococcus aureus, Bacillus cereus, Listeria monocytogenes, Clostridium perfringens, Escherichia coli, Salmonella choleraesuis and Candida albicans. This study confirms that the essential oil of $B$. graveolens demonstrates significant antimicrobial properties. The antioxidant activity was determined by using 2,2-diphenyl-1-picrylhydrazil (DPPH), the result, $\mathrm{IC}_{50}=545.25 \mu \mathrm{g} / \mathrm{mL}$, showed a weak antioxidant activity. The total phenolic content was found to be $5.71 \pm 0.16 \mathrm{mg} / 100 \mathrm{~g}$ using the Folin - Ciocalteu method. About the composition of this essential oil, it was submitted to hydrodistillation and analysis by gas chromatographic equipped with a flame ionization detector (FID). Twentysix compounds were identified, representing $67.1 \%$ of the total oil. The most abundant compound was $\alpha$-Terpinene (31.57\%). Thus, different types of monoterpenes were the predominant constituents of the essential oil.
\end{abstract}

Keywords: Bursera graveolens, Antimicrobial Activity, Antioxidant Activity, Total Phenolic, Terpinene.

\section{INTRODUCTION}

The study of the chemical components of essential oils from aromatic and medicinal plants is proving to have antioxidant, antibacterial, antiviral, antimycotic, antiinflammatory, and anti-tumor properties (Zaouali et al).The Bursera graveolens better known as palo santo or holy branch is a tree located in the dry forests on the north coast of Peru and they extend by the departments of Piura, Tumbes, Lambayeque and small portions of Cajamarca and La Libertad, and grow in generally sandy soils. This tree is known in traditional Peruvian medicine for helping ease symptoms of flu and asthma, dermal conditions, in addition also as antiinflammatory, soothing and relaxing proper- ties. The holy stick, of fragrant wood, is used as incense in the religious processions of the coast and mountain of this country. Antiinflammatory properties has been found in extracts of the bark of this plant (Manzano et al) and references to the oil chemical composition is poor. Studies of essential oil of steams and leaves of palo santo tree showed a large content of limonene (Leyva, et al). Based on a previous study of the composition and characteristics of this plant, the aim of this study was to evaluate the antioxidant and antimicrobial activities of B. graveolens.
DOI: 10.5530/ijper.51.3s.62 Correspondence:

María C. Alegría A. La Molina Calidad Total Laboratorios -Universidad Nacional Agraria La Molina, Av La Universidad s/n. Lima 12, PERÚ

Contact: +51-1941366744 E-Mail: calegria@lamolina. edu.pe 


\section{MATERIALS AND METHODS}

All the research was made in the Laboratories of physicalchemistry and microbiology of La Molina Calidad Total Laboratorios - UNALM, which is in Lima, the capital of Perú.

\section{Plant material}

Samples of dry wood logs were collected, in June 2011, belonging to Province of Department of Piura in Perú. This plant was used, cut and ground.

\section{Extraction of essential oil}

In order to observe if the method of extraction of essential oil influenced the antimicrobial activity, the ground wood were submitted to two methods of extraction: steam distillation and hydro-distillation type Clevenger (Bruneton, 1991), both of methods took $3 \mathrm{~h}$. Oils extractions were obtained by separation from the aqueous phase, dried with anhydrous sodium sulphate, filtered and stored in dark vials at $4^{\circ} \mathrm{C}$ for later analysis. Solutions of $150 \mu \mathrm{L}$ of oil in $100 \mathrm{~mL}$ of $\mathrm{n}$-hexane were prepared before GC.

\section{Chromatographic analysis}

GC analysis was carried out according to using for essential oils. Varian 450 gas chromatograph equipped with a flame ionization detector and attached to supelcowax TML 10 column (30 m x $0.53 \mathrm{~mm}$ ) was used. Two micro-liter of the sample, split 1:20 (disolved in hexane as $150 \mu \mathrm{L}$ of oil in $100 \mathrm{~mL}$ ) was injected into the system. The constituents were identified by comparing their relative retention time with those of authentic compounds injected in the same conditions.

\section{Antimicrobial activity}

The antimicrobial activity of essential oils of B. graveolens (obtained by steam distillation and hydro-distillation type Clevenger methods) was determined trough the agar disc diffusion.

\section{Microbial strains}

The antimicrobial activity was tested using $B$. graveolens oil against taphilococcus aureus ATTC 25923, Bacillus cereus ATCC 11778, Listeria monocytogenes wild, Clostridium perfringes ATCC 13124, Escherichia coli ATCC 25992, Salmonella choleraesuis ATCC 14028 and yeast Candida albicans wild. Bacterial strains were cultured by $24 \mathrm{~h}$ at $36 \pm 1^{\circ} \mathrm{C}$ in nutrient broth.

\section{Disc diffusion method}

The antimicrobial activity of oil was determined through the agar disc diffusion method. All tests were performed in twelve repetitions. The disc diffusion method was made according to Sacchetti et al. (2005). Triptic soy agar (TSA) was distributed into sterilized Petri dishes with a diameter of $9 \mathrm{~cm}(15 \mathrm{~mL})$ and Tripticase Soy Broth (TSB) was sterilized in autoclave at $121^{\circ} \mathrm{C}$ $\times 15$ min. For the yeast, Caldo Sabourud was used. Biochemical and confirmatory tests of the microorganisms were carried out before each use. The microorganisms were inoculated in TSA agar medium at $45^{\circ} \mathrm{C}$. The inoculum of bacterial strains used was $1 \times 10^{8} \mathrm{CFU} / \mathrm{mL}$ which was poured in TSA. The filter paper $(6 \mathrm{~mm}$ in diameter, Whatman $\mathrm{N}^{\circ}$ 4) were individually impregnant with $4 \mu \mathrm{l}$ of Bursera graveolens essential oil and then placed onto the agar plates. Before incubation, all Petri dishes were kept in the refrigerator $\left(4^{\circ} \mathrm{C}\right)$ for $2 \mathrm{~h}$ and incubated after at $36 \pm 1^{\circ} \mathrm{C}$ for $24 \mathrm{hr}$ for bacteria growth. After incubation the diameter $(\mathrm{mm})$ of the inhibition zones of the growth of microorganisms were measured including the diameter of discs. The activity was also evaluated according to Duraffourd C et al. (1986): Null $(-)$, if it was less than or equal to $8 \mathrm{~mm}$; Limit sensitivity $($ sensitive $=+$ ) from 9 to $14 \mathrm{~mm}$; (very sensitive $=++$ ) from 15 to $19 \mathrm{~mm}$ and highly sensitive $(\mathrm{S} . \mathrm{S}=+++$ ) if it was equal to or greater than $20 \mathrm{~mm}$. Oxytetracycline (gram-positive bacteria), chloramphenicol (gram-negative bacteria), fluconazole (yeast) served as a positive control.

\section{Antioxidant Activity}

The antioxidant activity was assessed by 2,2-Diphenil1-picrylhydrazyl (DPPH), Sigma-Aldrich brand. This method developed by Brand-Williams et al. (1995), is that the DPPH free radical, is highly reactive due to has a free electron, (violet blue color with methanol) which is decolorized to pale yellow color by reaction of an antioxidant substance. Both a methanolic solutions of DPPH $(20 \mu \mathrm{g} / \mathrm{mL})$ and essential oil of Bursera graveolens $(800 \mu \mathrm{g} / \mathrm{mL})$ were prepared. Neutralization reactions were made to these methanolic solutions, a Constance volume of DPPH radical and volumens of essential oil a different concentrations. The mixtures were then shaken and allowed to stand at room temperature in the dark. After $30 \mathrm{~min}$, the decrease in absorbance a $517 \mathrm{~nm}$ was measure against a blank (methanol solution) by using a Shimadzu Spectrophotometer model UV-160 A. The standard antioxidant substance used as reference control was Ascorbic Acid, Fisher brand. Essential oil of $B$. graveolens providing $50 \%$ inhibition $\left(\mathrm{IC}_{50}\right)$ was calculated form the plot of absorbance against essential oil concentration. Test were carried out in triplicate.

\section{Assay for total phenolics}

Total phenolic constituents of essential oil of Bursera graveolens was determinated by literature methods involving 
Folin-Ciocalteu's phenol reagent and gallic acid standard. Absorbance values were measured at $760 \mathrm{~nm}$. The same procedure was repeated for all the standard gallic acid solutions $(1-1000 \mu \mathrm{L} / 0.1 \mathrm{~mL})$.

Total phenols of the essential oil, as gallic acid equivalent, was determined by using the absorbance value of the essential oil measured at $760 \mathrm{~nm}$. Gest was carried out in triplicate and gallic acid equivalent value was reported as mean \pm SD of triplicate.

\section{Statistical analysis}

The results of antioxidant and antimicrobial activities were stated in mean \pm standard desviation using Minitab 17 th edition statistical software. The variations of diferents inhibitions zone by each microorganism were made by two methods (steam distillation and hydro-distillation type Clevenger) for each microorganism. All of them were tested by a variance analysis (Anova procedure) at $p<0.05$. The significance of differences between means was determined by Tukey at $\mathrm{p}<0.05$.

\section{RESULTS AND DISCUSSION \\ Chemical composition of the essential oil}

Dry wood logs were used, cut and ground. The essential oil was obtained by two methods of extraction: steam distillation and hydro distillation type Clevenger. Each of them took $3 \mathrm{~h}$ and both of them extractions were obtained by separation from the aqueous phase, dried with anhydrous sodium sulphate and filtered. The essential oil was stored at $4{ }^{\circ} \mathrm{C}$ protected from light, for later analysis.

The best yield, was obtained with hydro distillation by the Clevenger method. It was $3.59 \% \mathrm{v} / \mathrm{w}$. The yield by the steam distillation method was $1.63 \%$.on the basis of the weight of dried plant material.

Twenty-six compounds consisting up to of $67.1 \%$ of the essential oil were identified by GC (Table 1).The plant essential oil was consisted of $\alpha$-Terpinene (31.57\%), isocaryophillene (6.61\%), pyperitone (5.61 $\%), \beta$-trans-ocimene (4.93\%), 6-allyl-o-cresol (4.63\%), 1-tetradecen $3.27 \%)$, durenol $(2.36 \%)$, linalol $(1.53 \%)$, 3-octanol (1.1\%) germacren (0.92\%). Thus, different types of monoterpenes were the predominant constituents of the essential oil. This essential oil presents as a majority component to Monotherpene ( $\alpha$-terpene), followed by a sesquiterpene (isocaryophilene) and aliphatic alcohol (3 - octonal) also be present.

These results differ totally from the components that are obtained from the leaves and stems of this same plant with limonene as a priority component (Manzano, P et al. 2009). These differences are mainly due to the con- ditions of climate, temperature and geographical area. An analysis of constituents groups of essential oil of $B$. graveolens, showed oil possesses $37.5 \%$ of monoterpene hydrocarbons, $15.28 \%$ of oxygenated monoterpenes, and $8.55 \%$ of sesquiterpene hydrocarbons. Have not presented oxygenated sesquiterpenes. The $\alpha-$ Terpinene is the largest amount, following of Ocimene. Studies by Fernandez (2008) showed that $\beta$ - Trans ocimene presented antibacterian activity against Staphylococcus aureus and Enterococcus faecalis.

Thymol, although present in small quantities, is a phenolic compound well known for its antioxidant potential present in essential oils of plants (Aeschbach et al., 1994; Baratta, Deans, Biondi, \& Ruberto, 1998; Lagouri, Blekas, Tsimidou, Kokkini, \& Boskou, 1993. Antimicrobial effect also is reported (Castro Luna, 2008). B. graveolens essential oil may have mutagenic properties due to the presence of epoxy compounds. This group is very unstable and compounds are acting under a system of mutual collaboration or sinergism (Laouri et al.1993).

\section{Amount of total phenolic}

Based on the absorbance value of B. graveolens essential oil reacting with Folin - Ciocalteu phenol reagent and compared with the absorvance values of standard solutions of gallic acid, total phenolics contente of the essential oil was estimated as $5,71 \mathrm{mg} / 100 \mathrm{~g}$. This value indicstes that each 100 grams of essential oil contains phenolic compounds equivalent to about $5,71 \mathrm{mg}$ of pure gallic acid.

\section{Antioxidant Activity}

The results are present in Table 2. DPPH radical scavening activity by the Ascorbic Acid standard and bursera graveolens essential oil were expressed as IC50 values. The concentrations of analytes required for the conversión of the DPPH radicals by more stable molecule requiered a hight concentration of essential oil of Bursera graveolens $\mathrm{IC}_{50}=545.25 \mu \mathrm{g} / \mathrm{mL}$ against ascorbic acid $\mathrm{IC}_{50}=1.47 \mu \mathrm{g} / \mathrm{mL}$. This large value of concentration requiered by oil as an antioxidant is in accordance with low phenolic compounds content which was reflected in its Folin-Ciocalteu test. Although the antioxidant metabolites in plants are studied mainly based on their polyphenolic structures, there is a literature that reports that antioxidant activity is also found in essential oils whose components are mainly terpenoids and terpenoids. The composition of the essential oil of palo santo does not predominate the oxygenated monoterpenes to which the antioxidant power is attributed to them. Choi et al. (2000) report that linalool has a good antioxidant capacity against the radical DPPH, however, this mole- 
cule is present in the essential oil of B. graveolens in very low percentage, only $1.53 \%$. B-myrcene, $\beta$-pinene and limonene also show anti-radical activity against DPPH between 8.8 and 16.5\% uptake; in B. graveolens essential oil these substances are present in a low percentage of $0.02,0.28$ and $0.19 \%$ respectively.

Cuentas R, et al (2008) indicate that it is important to emphasize that the antioxidant activity is not only given by the sum of the antioxidant capacities of each component, it also depends on the microenvironment in which the compound is found, being able to interact with each other, producing synergistic or inhibitory effects.

\section{Antimicrobial activity}

The antimicrobial (anti-bactericidal and antifungal) activity of the essential oil Bursera graveolens obtained by steam distillation and Clevenger was determined by the Agar Diffusion Disc method against a panel of 7 microorganisms and their potency were assessed qualitatively and quantitatively by the present or absence and measuring of inhibition zones, zone diameters. The results are given in Table 3.

These results show that the pure essential oil of B. graveolens has substantially antimicrobial activity against all bacteria and yeast evaluated. Likewise, the antibiotics chloramphenicol, oxytetracycline and fluconazole were sensitive to gram positive bacteria, gram negative bacteria and fungi respectively.

The values of the microbial growth inhibition halos shown in Table 3 show slightly greater growth of inhibition halo by obtaining the essential oil by the Clevenger method than by the method of steam trapping except for the strain Candida albicans showing a greater result of the inhibition halo $(17.0 \pm 1.7 \mathrm{~mm})$ with the steam trapping method. The anaerobic bacterium C. perfringes, according to Duraffourd would be classified as extremely sensitive $(+++)$ to the oil, with a growth of the zone of inhibition corresponding to $24.3 \pm 1.5 \mathrm{~mm}$. C. albicans with a halo of inhibition of $14.6 \pm 1.8 \mathrm{~mm}$ and B. cereus with $13.3 \pm 1.3 \mathrm{~mm}$ correspond to a sensitivity classified as very sensitive $(++)$. The action of the essential oil was moderate with a sensitivity $(+)$ in gram positive strains, $S$. aureus and $L$. monocytogenes $(9.80 \pm$ 1.3 and $10.4 \pm 1.1 \mathrm{~mm}$ respectively) and gram negative strains, $S$. choleraesuis $(9.9 \pm 0.9 \mathrm{~mm})$. The antimicrobial activity of the essential oil B. graveolens is highlighted, by the two methods: vapor drag and Clevenger. The values obtained are higher than the antimicrobial activity of other essential oils. Tepe, B. (2005), reported that C. albicans was sensitive to the essential oil Salvia tomentosa but with a halo of inhibition of microbial growth equal to $12.5 \mathrm{~mm}$. In the case of the bacteria studied, the selected microorganisms are both morphologically and physiologically different then the values obtained are representative of the antibacterial activity that Bursera graveolens oil can present. In general, the antimicrobial activity of B. graveolens essential oil was more pronounced against gram positive bacteria than gram negative bacteria, a fact previously observed with other essential oils of other plant species (Nostro A, et al), (Outtara $\mathrm{B}$, et al). This generally higher resistance between gram negative bacteria has been attributed to the presence of their outer phospholipid membranes, almost impermeable to the lipophilic compounds present in the microorganism.

a Inhibition zone in diameter $(\mathrm{mm})$ around the impregnated discs.

b Antibiotics : CL, chloramphenicol; OX, oxitetracycline; FL, fluconazole

c NA (not applicable)

The results show that the essential oil has an inhibitory activity against $C$. perfringens higher than those reported by other oils. In addition, $C$. perfringes were found to have antimicrobial activity against extracts of Allium sativum (garlic), Coriandrum sativum (coriander), Eugenia caryopbyllata (clavode olor), Origanum vulgare (Oregano), Rosmarinus officinalis (Rosemary) and Thymus vulgaris (thyme), reporting inhibition halos of 19.4, 15.2, 14.9, 0, 14.4 and $0 \mathrm{~mm}$ respectively. Other studies on essential oils of Origanum vulgare and Thymus vulgaris, if they produced an inhibitory effect on $C$. perfringens; And also on other enteric bacteria such as E. coli, P. aeruginosa, S. aureus, B. cereus, L. monocytogenes, and C. botulinum, producing inhibition halos ranging from 7 to $24 \mathrm{~mm}$.

The inhibitory effect of essential oils has been well studied and is related to its composition. Substances such as thymol, carvacrol, linalool, cinnamic aldehyde, allicin and eugenol have proven inhibitory capacity. Its lipophilic action has the ability to pass cell membranes, break down polysaccharides, fatty acids and lipids, permeabilizing the cell membrane; Which leads to the loss of ions, to the collapse of the proton pump and to the decrease in ATP, which inevitably leads to cell death (Mattisek et al). The essential oil of B. graveolens does not present any of these components representatively however there is remarkable antimicrobial activity.

No reports have been found of the resistance of the strains to the essential oil under study but the inhibitory activity must be produced by synergistic effects between the components of the oil obtaining a significant activity and in some cases greater than other oils studied. Thus Candan F. (2003) reported antimicrobial activity in essential oil of Achillea millefolium subsp. Afan millefolium 
Table 1: Chemical composition of essential oil of B. graveolens (\%)

\begin{tabular}{|c|c|c|c|}
\hline $\mathbf{N}^{\circ}$ & T.R. , $\min$ & Compound & Composition ( $\%$ ) \\
\hline 14 & 4,26 & $\beta$-Pinene & 0.03 \\
\hline 15 & 4,68 & $\beta$-Pinene $(\uparrow S)$ & 0.28 \\
\hline 16 & 5,18 & $\beta$-Mircene & 0.02 \\
\hline 18 & 5,79 & $\alpha$ - Terpinene & 31.57 \\
\hline 20 & 6,14 & Limonene & 0.19 \\
\hline 21 & 6,86 & $\beta$-Felandrene & 0.48 \\
\hline 22 & 7,30 & $\beta$ - trans Ocimene & 4.93 \\
\hline 25 & 10,34 & Octyl acetate & 0.08 \\
\hline 29 & 12,22 & 3-Octanel(Amiletilcrabinol) & 1.1 \\
\hline 36 & 15,03 & 2S-trans-mentone & 0.51 \\
\hline 37 & 15,47 & Copaene & 0.42 \\
\hline 38 & 15,67 & 2R-Cis-Mentone & 0.02 \\
\hline 43 & 16,6 & Germacrene D & 0.92 \\
\hline 44 & 16,86 & Linalool & 1.53 \\
\hline 49 & 18,45 & Isocaryophillene & 6.61 \\
\hline 57 & 20,66 & a-Caryophillene & 0.46 \\
\hline 62 & 22,07 & 1-tetradecene & 3.27 \\
\hline 64 & 22,31 & Germacrene B & 0.14 \\
\hline 65 & 22,57 & Piperitone & 5.61 \\
\hline 66 & 22,72 & Epóxide & 1.35 \\
\hline 74 & 27,43 & Melonal & 0.22 \\
\hline 75 & 28,83 & Epóxide & 0.22 \\
\hline 76 & 29,52 & 6-Ally-O-cresol & 4.63 \\
\hline 81 & 38,05 & Thymol & 0.47 \\
\hline 83 & 39,86 & Durenol & 2.36 \\
\hline
\end{tabular}

Table 2: Inhibition concentrations of Ascorbic Acid standard and sample of B. graveolens essential oil against DPPH
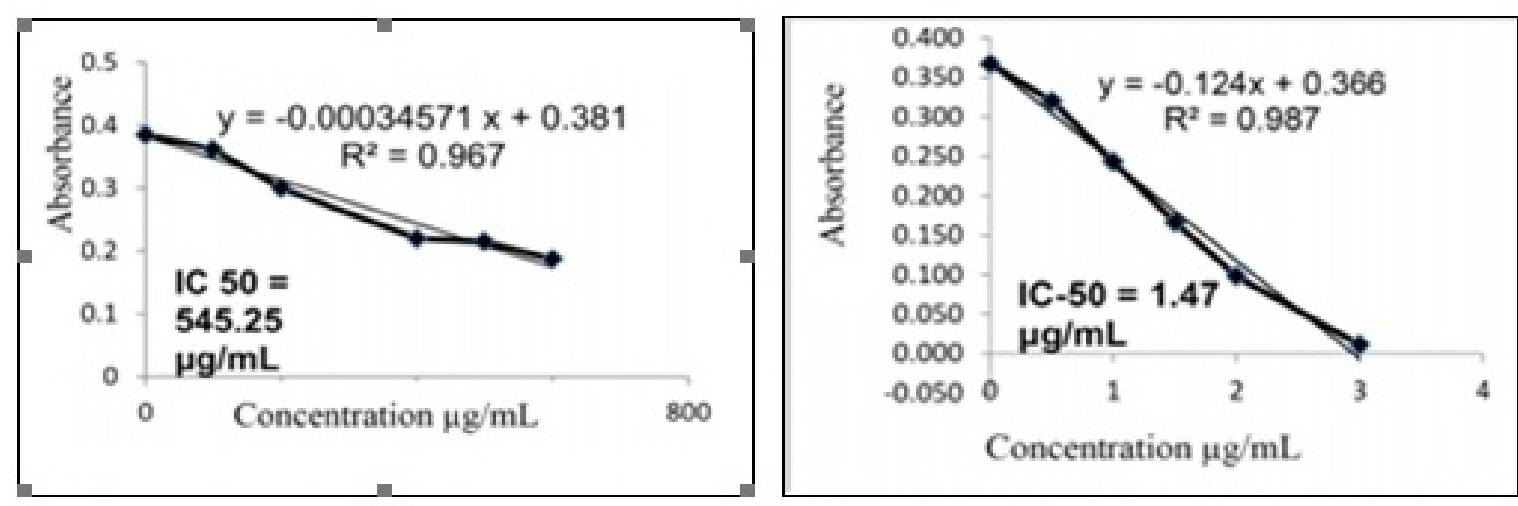


\begin{tabular}{|c|c|c|c|c|c|c|}
\hline Microorganism & Type & $\begin{array}{c}\text { Essential oil } \\
\text { obtained by } \\
\text { Clevenger } \\
\text { (4 } \mu \text { L/disco) } \\
\text { DD }^{a}\end{array}$ & $\begin{array}{c}\text { Essential oil } \\
\text { obtained by } \\
\text { steam distillation } \\
\text { (4 } \mu \text { L/disco) } \\
\text { DD }\end{array}$ & $C L^{b}$ & OX & FL \\
\hline & Gram - Positive & & & & & \\
\hline S. aureus & ATCC 25923 & $9.8 \pm 1.3$ & $9.3 \pm 0.9$ & $N A^{c}$ & $17.8 \pm 1.5$ & NA \\
\hline B. cereus & ATTC 11778 & $13.3 \pm 1.3$ & $12.8 \pm 0.9$ & NA & $27.2 \pm 1.1$ & NA \\
\hline L. monocytogenes & Wild & $10.4 \pm 1.1$ & $8.1 \pm 0.8$ & NA & $21.4 \pm 2.4$ & NA \\
\hline \multirow[t]{2}{*}{ C. perfringens } & ATTC 13124 & $24.3 \pm 1.5$ & $15.8 \pm 0.9$ & NA & $36.5 \pm 2.0$ & NA \\
\hline & Gram - Negative & & & & & \\
\hline E. coli & ATCC 25922 & $10.2 \pm 0.9$ & $9.4 \pm 0.9$ & $20.6 \pm 1.0$ & NA & NA \\
\hline \multirow[t]{2}{*}{ S. choleraeuis } & ATTC 14028 & $9.9 \pm 0.9$ & $9.8 \pm 1.2$ & $22.0 \pm 1.6$ & NA & NA \\
\hline & Fungi & & & & & \\
\hline C. albicans & Wild & $14.6 \pm 1.8$ & $17.0 \pm 1.7$ & NA & NA & $18.3 \pm 2.6$ \\
\hline
\end{tabular}

against S.aureus, B.cereus, E. coli and C.perfringens with microbial growth inhibition halos equal to $8,10,0$ and $12 \mathrm{~mm}$ respectively, values lower than those reported by palo santo of $9.8,13.3,10.2$ and $24.3 \mathrm{~mm}$ (Table 3). A recent study by Benites $\mathrm{J}$ et al. determined the antibacterial activity of essential oil in leaves and stems of Senecio atacamensis Phil of Chile against $\mathrm{S}$. aureus and E. coli reporting for the former a HICM $=10.5 \pm 0.7$ $\mathrm{mm}$, similar to that reported in the essential oil of palo santo $(\mathrm{HICM}=11.0 \pm 0.5 \mathrm{~mm})$ whereas for the latter it did not report antibacterial activity, whereas in the essential oil of B. graveolens an HICM was obtained $=10.0 \pm 0.8 \mathrm{~mm}$. The essential oil of Senecio atacamensis Phil presented among its main components the $\alpha$-terpinene, $\alpha$-phellandrene and $\mathrm{p}$-cymene while the palo santo essential oil reported $\alpha$-terpinene as its main component.

Essential oils are very complex mixtures containing a wide variety of components. Thus, it can be argued that the antimicrobial effect is observed as a result of the activity of the active compounds, as well as the possible synergistic effects between the minor components that accompany it. The mechanism of action of terpenes is not fully understood, but is speculated to involve membrane disruption of lipophilic compounds (Cowan, 1999).

\section{CONCLUSION}

The essential oil of B. graveolens presents a strong antimicrobial activity against all the microorganisms studied. Especially against Clostridium perfringens with a diameter of inhibition equal to $24.3 \mathrm{~mm}$ and against the yeast Candida albicans with an inhibition diameter equal to $17 \mathrm{~mm}$. The oxidant activity is low with an $\mathrm{IC}_{50}$ of $545.25 \mu \mathrm{g} / \mathrm{mL}$.

\section{ACKNOWLEDGEMENT}

This research was supported by La Molina Calidad Total Laboratorios and Department of Chemistry of National Agrarian University - La Molina, are acknowledged for their help in the chemical and microbiological analysis of the essential oil.

\section{CONFLICT OF INTEREST}

None

\section{ABBREVIATION USED}

TSA: Tryticase soy agar; TSB: Trypticase soy broth; DPPH: 2,2-Diphenil-1-picrylhydrazyl; HICM: zone of inhibition of microbial growth; IC50: half maximal inhibitory concnetration; CL: chloramphenicol; OX: oxytetracycline; FL: fluconazole; FID: flame ionization detector.

\section{REFERENCES}

1. Plaus AE, Flores SG, Ataucusi GS. Chemical composition and antibacterial activity of the essential oil of Origanum vulgare (oregano). Rev Med Hered. 2001;12(1):16-9.

2. Alzamora L, Morales L, Armas L, Fernández G. Traditional Medicine in Peru: In vitro Antimicrobial Activity of Essential Oils Extracted from Some Aromatic Plants. Annals of Faculty of Medicine UNMSM. 2001;62(2):156-61.

3. Ardila M, Vargas A, Pérez J, Mejía L. Preliminary test of the antibacterial activity of Extracts of Allium sativum, Coriandrum sativum, Eugenia Caryophyllata, Origanum vulgare, Rosmarinus officinalis and Thymus vulgaris against Clostridium perfringens. Biosalud. 2009;8(1):47-57.

4. Bakkali F, Averbeck S, Averbeck D, Idaomar M. Biological effects of essential oils. Food and Chemical Toxicology. 2008;46(2):446-75. 
5. Bassole L, Ouattara A, Nebie R, Ouattara C, Kabore Z, Traore S. Chemical composition and antibacterial activities of the essential oils of Lippia chevalieri and Lippia multiflora from Burkina Faso. Phytochemistry. 2003;62:209-12.

6. Bektas T, Dimitra D, Atalay S, Munevver S, Moschos P. Antimicrobial and antioxidant activity of essential oil and various extracts of Salvia tomentosa Miller. Food Chemistry. 2005;90:333-40.

7. Benites J, Bravo F, Rojas M, Fuentes R, Moiteiro C, Venancio F. Composition and antimicrobial srceening of the essential oil from the leaves and stems of Senecio atacamensis. Phil. From Chile. J. Chi Chem Soc. 2011;56(2):712-4.

8. Brands-Williams $W$, Cuvelier M, Berset $C$. Use of free radical method to evaluate antioxidant activity. Lebensmittel Wissenschaft und Technologie. 1995;28(1):25-30.

9. Bruneton J. Elements of Phytochemistry and Pharmacognosy. Editorial Acribia. Zaragoza, Spain. 1991.

10. Candan F. Unlu M, Tepe B, Daferera D, Polissiou M, et al. Antioxidant and antimicrobial activity of the essential oil and methanol extracts ofAchillea millefolium subsp. Millefolium Afan. J. Ethnopharmacology. 2003;87(2-3): 215-20.

11. Carhuapoma M, Bonilla P, Suarez S, Vila R, López S. Study of Chemical Composition and Antioxidant Activity of Essential Oil of Luma check (Molina) A. Gray "arrayan". UNMSM. Faculty of Pharmacy and Biochemistry. Science and Research. 2005;8(2):73-9.

12. Yance CM. Chemical composition, anti-Helicobacter pylori activity and antioxidant of the essential oil of Satureja brevicalyx Epling "urqu muña (Doctoral Thesis), UNMSM, Faculty of Pharmacy and Biochemistry, Lima, Peru.

13. Castañeda $C$, Ramos Q, Ibañez $L$. Evaluation of the antioxidant capacity of seven Peruvian medicinal plants. Medical Journal. 2008;8(1):56-72.

14. Castro A. Chemical composition of the essential oil of the leaves of Erythroxylum novogranatense (Morris) coca, Antioxidant activity and antibacterial determination against Streptococcus mutans. (Doctoral thesis) Post-graduate unit - Faculty of Pharmacy and Biochemistry of the UNMSM. Lima Peru. 2008.

15. Choi H, Song SH, Ukeda H, Sawamura M. Radical-Scavenging activities of Citrus essential oils and their components: detection using 1,1-diphenyl-2picrylhydrazyl. J Agric Food Chem. 2000;48(9):4156-61.

16. Cowan M. Plant products as antimicrobial agent. Clin Microbial. 1999;12:564-82.

17. Cruz DL, Hernández G, Mateo L, Castañeda C, Ibañez L, et al. Evaluation of the antioxidant effect of leaves of Lepidium peruvianum Chacón, "maca". Journal Horizon. 2008;8(1):45-55.

18. Duraffourd C, \& Lapraz, J.C. Clinical Phytotherapy Notebooks. Editorial Masson. Mexico. 1986
19. Hersch-Martinez P, Leanos-Miranda B, Solorzano-Santos F. Antibacterial effects of commercial essential oils over locally prevalent pathogenic strains in Mexico. Phytotherapy. 2005;76(5):453-7.

20. Jaramillo, B. et al. Volatile chemical composition of croton essential oil malambo H. Karst. And its antioxidant activity. Cuban Journal of Medicinal Plants. 2010; 15 (3): 133-142.

21. Jaramillo B, Stashenko E, Martínez J. Volatile chemical composition of Satureja brownei (Sw) Colombian Briq and determination of its antioxidant activity. Cuban Journal of Medicinal Plants, 2010;15(1):52-63.

22. Jiang $\mathrm{CH}$, Liu QZ, Du SS, Deng ZW. et al. Essential oil composition and insecticidal activity of Evodia lepta (Spreng) Merr. Root barks from China against two grain storage insects. Med Plants Research. 2012;6(18):3464-9.

23. López A, Oré R, Miranda $\mathrm{C}$, Trabucco J, Oihuela $\mathrm{T}$, Linares $\mathrm{J}$, et al. Antioxidant capacity of wild populations of "tara" (Caesalpinia spinosa) from the localities of Picoy and Santa Fe (Province of Tarma, department of Junín). Scientia Agropecuaria. 2011;2:25-9.

24. Mattisek R, Schnepel F, Steiner G. Food analysis. Fundamentals, Methods, Applications. Editorial Acribia S.A. Zaragoza, Spain. 1998.

25. Nostro A, Germano M, D'Angelo V, Marino A, Cannatelli M. Extraction methods and bioautography for Evaluation of medicinal plant antimicrobial activity. Letters in Applied Microbiology. 2000;30(5):379-84.

26. Outtara B, Simard R, Holley R, Piette G \& Bégin A. Antibacterial activity of selected fatty acids and essential oils against six meat spoilage organisms. International Journal of Food Microbiology. 1997;37(2):155-62.

27. Ponce AG, Fritz R, del Valle CE, Roura S. Antimicrobial activity of essential oils on native microbial population of organic Swiss Chard. LebensmittelWissenschaft und-Technologie. 2003;36(7):679-84.

28. Carrasco R, Encina C. Determination of the antioxidant capacity and bioactive compounds of Peruvian native fruits. Rev Soc. Quím Perú. 2008;74(2):108-24.

29. Tepe B, Sokmen M, Askin H, Daferera D, Moschos P, Sokmen A. Antioxidative activity of the essential oils of Thymus sipyleus subsp. Sipyleus var. Sipyleus and Thymus sipyleus subsp. Sipyleus var. Rosulans.Journal of Food Engineering. 2005;66(4):447-54.

30. Wang W, Wu N, Zu YG, Fu YJ. Antioxidative activity of Rosmarinus officinalis L., Essential oil compared to its main components. Food Chemistry. 2008;108(3):1019-22.

31. Zaouali Y, Bouzaine T, Boussaid M. Essential oils composition in two Rosmarinus officinalis $L$ varieties and incidence for antimicrobial and antioxidant activities. Food and Chemical Toxicology. 2010;48(11):3144-52.

32. Zapata B, Duyran C. Stashenko E, Betancur-Galvis L, Mesa-Arango AC. Antifungal and cytotoxic activity of essential oils of plants of the family Asteraceae. Iberoamerican Journal of Mycology. 2010;27(2):101-3.

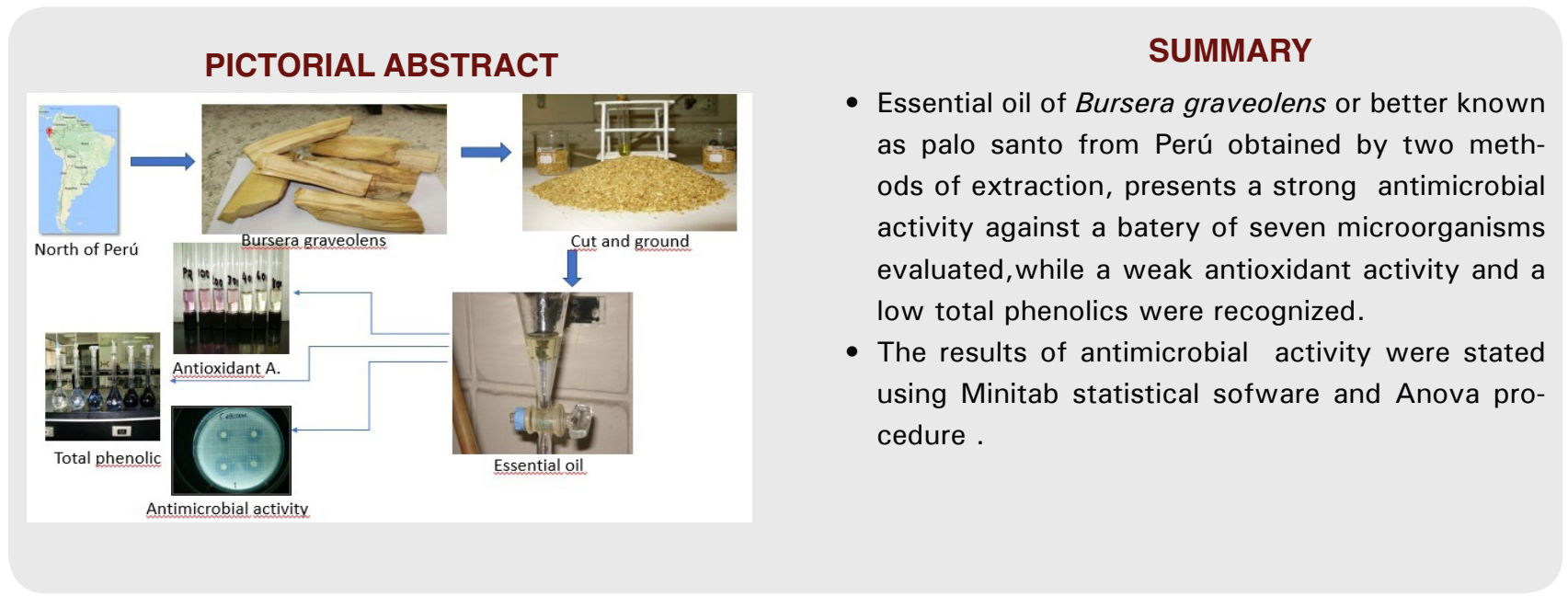




\section{ABOUT AUTHORS}

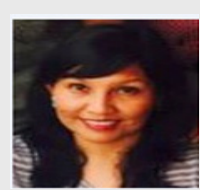

Mg.Sc. María C. Alegría: Working as Principal Professor of Department of Chemistry and Technical Director of La Molina Calidad Total Laboratorios, National Agrarian University - La Molina, Lima, Perú.

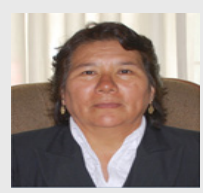

Mg.Sc. Alejandrina H. Sotelo: Working as Principal Professor of Department of Nutrition and Executive Director of La Molina Calidad Total Laboratorios, National Agrarian University - La Molina,Lima,Perú.

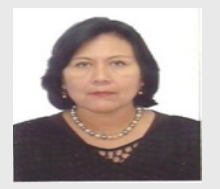

Mg. Sc. Clara Figueroa Cornejo: Working as Principal Professor of Department of Chemistry and La Molina Calidad Total Laboratorios, National Agrarian University - La Molina, Lima-Perú.

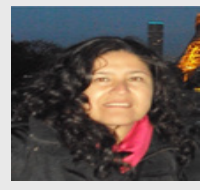

Mg. Quím. Mary Flor Césare Coral: Working as Principal Professor of Department of Chemistry - La Molina Calidad Total Laboratorios, National Agrarian University - La Molina, Lima - Perú.

Cite this article: Sotelo AH, Figueroa CG, Césare MF, Alegría MC. Chemical Composition, Antimicrobial and Antioxidant Activities of the Essential Oil of Bursera graveolens (Burseraceae) From Perú. Indian J of Pharmaceutical Education and Research. 2017;51(3)Suppl:S429-36. 